\title{
Governance and State Effectiveness in Asia
}

\author{
Hossain Zillur Rahman and Mark Robinson
}

\begin{abstract}
1 Introduction
This article examines Asian strategies for improving governance and the effectiveness of state institutions. It reviews interpretations of governance that are relevant and appropriate to the Asian context and how these complement or differ from broader definitions. The article considers the rich variety of experience across Asia, in terms of variations in types of regimes, governance indicators and trajectories of reform. It takes stock of Asian-led approaches to improved governance by considering the varied impetus for reform in different countries of the region, as well as how far measures designed to improve the effectiveness and accountability of state institutions have generated positive outcomes for growth and poverty reduction.
\end{abstract}

The article demonstrates that successful approaches are premised on country ownership of reform initiatives, incremental approaches that strengthen political commitment, and an extended timeframe for implementation. It concludes that there is considerable scope for sharing lessons of successful experience more widely through bilateral initiatives and regional organisations, and through aid donors supporting Asian-led approaches through appropriate entry points for reform that are politically feasible and can generate public support.

\section{Pathways to better governance 2.1 Definitions and scope}

Governance has a wide variety of meanings, ranging from a narrow concern with the manner in which the state acquires the authority to manage public goods and services, through to the accountable, transparent and legitimate use of state power. Other approaches emphasise the importance of

participation in decision-making processes and the linkages between civil liberties and poverty reduction.
From the perspective of most Asian countries, the extent to which the state creates an institutional environment that maximises the opportunities for growth and poverty reduction is the most critical dimension of governance. ${ }^{1}$ It also accords with a perspective to which many bilateral and multilateral aid donors subscribe. The Asian Development Bank (ADB), for example, lists accountability, participation, predictability and transparency in its definition of governance. The UK Department for International Development (DFID) highlights four interrelated elements of effective states: authority, responsiveness, accountability and legitimacy, which resonate strongly with emerging Asian governance priorities. ${ }^{2}$

The state is central to Asian-led strategies for promoting growth and poverty reduction. $A$ supportive policy environment to foster trade, investment and technological development is a critical determinant of the economic success of many countries in the region. Government policy designed to mitigate the effects of rapid growth has an important bearing on sustainability, through strategies to manage the adverse environmental consequences of rapid industrialisation and to address growing inequality between regions and social groups.

Public investment in infrastructure or human capital plays an important role in shaping development prospects. Sustained public investment in roads, bridges, ports and communications is associated with higher rates of trade and investment. Governments that have invested heavily in education reap the benefits of a skilled workforce that attracts investment and creates employment opportunities.

Capable states in Asia have skilled and motivated public bureaucracies. The public sector remains a 
major source of formal employment in many Asian countries. Graduates from leading universities in the region seek top positions in government but there are now growing employment opportunities in the private sector. Several countries are in a process of transition from recruitment and promotion systems characterised by patronage and seniority to ones in which qualifications and merit predominate. Privatisation and public sector reform are also changing the role of public servants from an emphasis on administration to management, where top-down controls are giving way to flexible regulatory structures.

But the continued centrality of state institutions in many Asian countries also poses governance challenges. Corruption is a problem faced to varying degrees by many Asian countries, mirroring the experience of Western countries in earlier phases of development. Corruption diverts scarce public resources to private ends, it acts as a disincentive to investment, and places a disproportionate burden on poor consumers of public services. Governments in the region have been making efforts to contain the problem through the formation of anti-corruption agencies, vigilance commissions and improved legal measures to punish corrupt officials. These are beginning to produce results, but more can be done to reduce the opportunities and incentives for corruption.

Government bureaucracies are often unresponsive to citizens' demands and lack transparency in managing public resources. And yet several countries in the region promote financial management reforms to improve budgeting procedures, the predictability of expenditure forecasts, and financial accountability. Others are engaged in a steady process of decentralisation to bring government closer to people at the local level.

Greater openness about governance challenges need not be perceived as a threat to governments in the region. Growing recognition that failure to address pressing governance challenges may retard growth and deepen inequality has spurred many Asian governments into taking action.

\subsection{Bridging governance perspectives}

Governance is not only a matter of structural attributes of states. It is also about values, processes and outcomes. For example, establishing an anti- corruption commission is easier than making it into an effective deterrent against corruption based on a broader social consensus. It is important to acknowledge that governance reform priorities may differ among distinct social groups. The predominance of elite perceptions of governance in policy and public discourse underlines the need to complement institutional and legal approaches with a focus on the rights and needs of the poor. The everyday reality of the poor and the marginalised in particular, and for citizens as a whole, is as important as the constitution and the legal framework for framing governance reform priorities.

Differing perspectives on reform priorities may also be seen in more practical terms. Politicians, for example, are likely to be more concerned about the political implications of different kinds of reform and might give priority to those that increase satisfaction among their supporters. Bureaucrats may favour technocratic solutions over those that require greater social engagement and broaden participation. Aid donors tend to emphasise the efficient management of public resources and greater accountability in the use of these resources. Economic elites might prioritise reforms that improve their capacity to do business and generate profits by holding government bureaucracies to account and improving the security environment. Poor people, in contrast, are more likely to emphasise the availability of services and the linkages between personal security and improved livelihoods.

For these reasons it cannot be assumed that different social and political actors have similar priorities. The challenge lies in resolving the tradeoffs between these competing perspectives. Greater agreement on core governance priorities in the region can generate the social consensus necessary to take the reform agenda forward.

Bridging governance perspectives is not only required for reform objectives but also for clarity on how these will be achieved. Producing tangible benefits in the short term is often a necessary first step to opening up larger reform agendas. Recent examples from Bangladesh are the campaign against cheating in public examinations and enhanced security in public markets during festival periods. These serve the crucial function of high visibility changes that build citizens' trust in the possibility of deeper reform. More ambitious and challenging reforms 
need to be assessed in terms of their political feasibility and the context into which they will be introduced. The overall goal of better government performance is not advanced when governments promise actions that are not politically or bureaucratically feasible or when they cannot deliver on their promises. The challenge is not so much on the ambition and duration of the reform agenda, but rather how reforms are introduced and sustained in the real world.

Real-life constraints impinging on the potential receptiveness of political actors to governance issues also merit attention. In open political systems, maintaining political capacity vis-à-vis contenders for power is a basic imperative for politicians. Such preoccupations often result in predatory behaviour but are often protective and discourage active engagement on governance issues. $A$ less acknowledged constraint is the pressure for responding to the electorate's expectations of 'development', which often translates into visible infrastructure such as roads, bridges, schools and hospitals. Better appreciation of how citizens understand development priorities highlights the value of investing in new symbols, which promote growth and poverty reduction and allow for stronger engagement on governance goals.

It is also important to acknowledge that not all desirable governance outcomes are amenable to immediate policy intervention. In many areas of social, institutional and political behaviour, the challenge often requires gradual acceptance of societal norms as much as policy action. The comparatively recent phenomenon of queuing for a bus on the streets of Dhaka is a classic illustration of norm graduation, a change brought about not by policy but through a shared realisation by a sufficient number of people that queuing is appropriate behaviour. For policy making to be successful it is important to be clear about the limits of policy. Citizens' responsibilities in creating ethical, behavioural and work standards in critical areas of social, political and professional life cannot be overlooked.

\subsection{Governance and the Millennium Development}

\section{Goals in Asia}

While better governance is a compelling goal in its own right, within the Millennium Development Goal (MDG) context, making governance work for the poor is the greater challenge. Exploring the reasons why governance is germane to MDG attainment and the broader fight against poverty is critical to a sharper formulation of governance priorities. To a significant extent, the issue here is a better understanding of where the perceived governance 'needs' of the poor lie.

These would appear to be in the following areas: (1) better service-delivery, particularly in the areas of health and education; (2) reduction of leakages in targeted anti-poverty programmes; (3) access to justice; (4) regulatory support to the informal and unorganised sectors of the economy where a majority of the poor pursue their livelihoods; (5) better support in coping with disasters; and (6) reduction of income erosion threats to the poor due to various forms of insecurity and improper application of power. Above and beyond these priorities, the poor share with the rest of society two common governance 'needs': increasing the strategic efficiency of the state to address growth and distributive justice, and democratisation of the discourse and practice of power. However, progress has been uneven both in the acknowledgement of these governance priorities and in their fulfilment.

A word of caution is necessary here. The policy emphasis on the MDGs that has been so instrumental in broadening the development discourse is beginning to result in some unintended consequences. The emphasis on summary indicators, such as enrolment rates, has unwittingly spawned a 'shortcut mentality' among political leaders and other actors on the operational challenge of achieving human development. Political dividends are being sought in a rather narrow interpretation of performance and this often appears to be coming at the cost of a more holistic and strategic engagement with the education challenge. Asian success stories on education - from Japan, Malaysia and Sri Lanka have precisely been those which from the beginning adopted a holistic and strategic formulation of education policy. Clearly, for Asian countries with large poverty-stricken populations, a simplistic access paradigm is not enough and needs to be combined with a focus on quality.

\subsection{Big solutions, small solutions}

There is also a mindset challenge in being more effective in addressing pressing governance priorities. The governance agenda is often formulated in the language of 'big solutions', while neglecting the 
window of 'small solutions' which can be initiated quickly with much less of a challenge for policy innovation. $A$ recent useful contrast here relates to the 'big solution' of reforming the land record system in Bangladesh. Though efforts on this front are nearly a decade old, progress to date has remained elusive. In contrast, an effective 'small solution' was the recent change in the Stamp Act in Bangladesh, a small administrative innovation by a reform-minded bureaucrat, which has produced multiple benefits. In one modest stroke, the amendment has led to cost savings for the government, removed some of the institutional sources of corruption around the printing, distribution and forgery of stamp papers, reduced the bureaucratic load on the sub-registry offices, and reduced the hassle for the buyers and sellers of land. An active search for such 'small solutions' has been a missing focus in the contemporary governance agenda. Micro-governance agendas are important not only because they can prove to be effective entry points to pry open intractable macro-governance agendas, but because they can also provide a real-life demonstration of what is feasible in contexts which may not be amenable to more ambitious reform. ${ }^{3}$

\subsection{From decentralisation to local governance}

The traditional discourse on decentralisation with its statist focus on local governments no longer accords with ground realities where migration is a pronounced phenomenon, integration into the globalisation process is well under way, and newer social forces are on the horizon with which local governments must find meaningful linkages. Changing ground realities in effect require a transition to a new paradigm, one of local governance with an emphasis on livelihoods (Rahman and Aminul Islam 2002). Local governance broadens the focus beyond local governments to include nongovernmental organisations (NGOs), community organisations and the private sector, and highlights the importance of combined efforts towards concrete and specific goals. A two-track strategy is increasingly called for: a political agenda of administrative and financial devolution, and a functional agenda of service delivery, disaster management, affordable justice, and local economic regeneration for which local governments build viable coalitions with these social actors.

The importance of the two-track strategy can be seen from the contrasting outcomes in Bangladesh and the neighbouring Indian state of West Bengal.

West Bengal has had a much publicised and successful decentralisation programme in contrast to Bangladesh, where local governments have remained very much subordinate to the central administration. A comparison of outcomes on the ground, however, offers some striking insights. While the strong political decentralisation process in West Bengal has created an impregnable electoral fortress for the ruling political alliance in the state, the politically weaker Bangladesh experience appears to have compensated for lack of progress in political devolution through better social outcomes. Bangladesh villages stand out for their superior infrastructure and social indicators on health and education (World Bank/ADB 2002).

\subsection{Importance of evidence and indicators}

Evidence on governance requires both the credible generation of data and conceptually sound interpretation. Statistical agencies, independent research institutions and civil society organisations all have a role to play in addressing the empirical and analytical challenge. In this regard, evidence on corruption has tended to be strongly influenced by an emotive approach that focuses on perceptions and beliefs. Even though it is derived from real-life experience, such an approach ends up highlighting a narrow institutional agenda centred on deterrence while neglecting the imperative of building a wider political consensus around corruption and its causes. The development of indicators that are appropriate to local context can give rise to a broader reform agenda and facilitate monitoring of progress.

The Asian record of robust growth and inadequate political governance highlights the urgency of unpacking the governance debate. Do all aspects of governance have to move in tandem or does it make sense to distinguish between political and economic governance and the possibility of differential progress? It is in the search for answers to this and other less than obvious questions that the Asian experience offers lessons for replication elsewhere and for identifying the critical gaps which Asian countries must address in their journey forward.

3 Lessons from Asian experiences on governance initiatives

\subsection{Governance regimes in Asia}

Sustained growth and poverty reduction has taken place under a range of different governance regimes 
in Asia. State-led industrialisation with trade liberalisation was the principal driver of rapid growth and poverty reduction in East Asia, with concerted attention to lagging regions through resource transfers. Substantial progress was achieved by capable, centralised governments in countries as varied as South Korea and Taiwan in the 1960s and 1970s, and China and Vietnam in the 1990s.

Progress under competitive regimes in South Asia has been more gradual. Economic growth accelerated in the 1990s in Bangladesh, India and Sri Lanka as a result of selective trade and price liberalisation but without fundamental improvements in state capacity and the calibre of the public service. Steady progress was achieved in poverty reduction through a combination of employment generation and targeted transfers to poorer regions and communities.

Less progress has been achieved under partial democracies in Cambodia and Pakistan, which are characterised by political instability and a legacy of authoritarian rule. Growth performance has been modest while progress on poverty reduction and the MDGs is limited.

States ruled by autocratic governments and facing large-scale insurrection - such as Burma and Nepal have made least progress. Poor economic performance and limited progress on poverty reduction have gone hand in hand with problems of governance. Political instability has deterred investment, while the ability of the state to address poverty is limited by capacity constraints and diversion of public resources to military spending.

Hence, no single model of governance is associated with positive growth and poverty outcomes across Asia; there has been progress both in centralised East Asian polities and democratic governments in South Asia. Sustained progress on growth and poverty in East Asia was achieved under capable states but progress on other dimensions of governance followed later. In South Asia, the achievements on growth and poverty reduction were more modest but many countries maintained a positive record on governance. While the greatest challenges emanate from problems of authoritarian rule and weak capacity in failing states or unconsolidated democracies, there is an impetus towards improvements in governance in a number of Asian countries.

\subsection{Drivers of governance reforms}

Patterns of governance in successful Asian economies are changing. $A$ variety of factors are at work, ranging from the effects of domestic liberalisation, responses to globalisation and international trade regimes, to demands for better governance voiced by citizens (Cheung and Scott 2003a). A further factor is the influence exercised by aid donors, through programmatic support for governance initiatives developed by Asian governments or aid conditionality.

Over the past two decades, many countries in Asia have followed the path of economic liberalisation through deregulation, privatisation and public sector reform. This has fundamentally changed the role and functions of the state, from economic intervention through the public sector to creating a regulatory regime to encourage private economic activity. State action is increasingly geared towards creating the right policy and institutional environment to facilitate growth, rather than on controls and directives.

Globalisation and increased trade have exposed Asian economies to competitive pressures and global standards. Far from undermining progress, most Asian countries have adjusted their policies and institutional practices to take advantage of the new global trading regime under the auspices of the World Trade Organization (WTO). Conformity with WTO standards has required changes in trade policy, adjustment to new tariff regimes and the acquisition of new knowledge and capacity. Asian governments have responded to the challenge of globalisation through more robust engagement in WTO negotiations, more aggressive export promotion and deepening expertise on trade policy (Weiss 2003). The 1997 financial crisis in East Asia has vividly demonstrated how economic problems can result from poor governance, and governments in the region are taking steps to avert recurrence of such an event.

A third source of reform lies in citizen-led demands for better governance. Rising expectations of greater responsiveness on the part of governments are not confined to elected governments in the region. For example, the 2002 World Values Survey shows a striking breadth of public support for a democratic form of government in East Asia across countries and various types of regime. Democratic aspirations among East Asians are only marginally lower than 
their fellow citizens in North America (Dalton and Shin 2003). ${ }^{4}$ While citizens may not actively mobilise for improvements in governance, there is a groundswell of popular support for reforms that improve the efficiency, accountability and transparency of government, as revealed by public opinion surveys and media coverage. ${ }^{5} \mathrm{~A}$ growth in the number of taxpayers provides further impetus towards accountability in the use of public resources.

At times, organised citizens - business people, NGOs and social activists - have taken the initiative in responding to problems of poor governance, which in turn can provoke action from the relevant authorities and lead to the scaling up of local initiatives. For example, local businesses in the Pakistan city of Karachi instigated the formation of citizen-police liaison committees to address the problem of crime and extortion (Masud 2002). In rural Bangladesh, NGO efforts to improve the dispute-resolution process have led to alternative dispute-resolution mechanisms gaining acceptance in law. ${ }^{6}$ The right to information movement in Rajasthan was very influential in persuading state and national governments in India to enact right to information legislation.

Aid donors can influence the governance agenda in Asian countries through the provision of financial resources and technical advice. This can be significant in the less-developed countries of the region that receive more aid, such as Bangladesh, Cambodia and Nepal, and provide an important impetus for galvanising domestic reform initiatives. But in general, aid donors have not played a critical role in promoting governance reform in the region, particularly in the larger countries such as China and India, which are less amenable to external engagement. On the whole, attempts to exert conditionality over poor governance indicators or the slow pace of reform have not resulted in significant progress or strengthened implementation.

\subsection{Asian-led approaches to improved governance}

While some of the factors propelling governance reform in Asia are common across countries, these have followed different trajectories in line with variations in regime characteristics, political culture, state capacity and levels of societal mobilisation.

South Asian political culture tends towards pluralism and lack of conformity, rendering it more challenging for governments to build consensus around shared vision and values. Governance reforms in South Asia are frequently characterised by weak political commitment, limited bureaucratic capacity and uneven public support. National and state governments in the Indian subcontinent have tended to pursue an incremental approach, where reforms do not command significant visibility, where they do not threaten vested political or bureaucratic interests, and where there is scope to marshal public support (Manor 2006). But incremental approaches often require a protracted time period for visible results to be achieved.

There are some positive examples of governance reform from South Asia, where committed politicians have introduced a range of reforms designed to improve the accountability and effectiveness of government. These include the state governments of Andhra Pradesh, Karnataka and Madhya Pradesh in India, where a range of reform experiments were rolled out by chief ministers from the late 1990s. But in each case, the governments that had introduced the reforms were subsequently voted out of power in state elections, highlighting the difficulty of mobilising political support for governance reforms.

Domestic political commitment enhances the political feasibility of governance reform and takes attention away from a prescriptive donor agenda. Politicians in South Asia have used donor support to their advantage in mobilising financial support and technical assistance for reforms, but distance themselves from donors when reform initiatives provoke domestic criticism.

East Asian governments, by comparison, tend to be strongly institutionalised, centralised and conformist. There is a relatively high level of bureaucratic capacity, especially at higher levels of the civil service and in technocratic policy-making units. There is a strong sense of political direction and vision, but relatively limited scope and capacity for social mobilisation.

The domestic impetus for governance reform in East Asia varies across countries. Most reforms have emanated from a strong sense of political commitment and several governments in the region have not shied away from difficult reforms. Political leaders in some countries have sought to make a 


\section{Box 1 Improving the civil service in China}

The Chinese government implemented a series of deep cuts in the core civil service in the 1990s to reduce the financial burden of an overextended bureaucracy, entailing staffing reductions in the order of 30 per cent. The impact of China's civil service reform programme is significant. Changes in recruitment policy towards greater emphasis on merit have led to dramatic improvements in the education level of civil servants, with the proportion of leading bureaucratic cadres possessing a university degree rising from 20 to 80 per cent from 1980 to 1998. Alongside this trend, the average age of top officials has also fallen significantly. These changes have in turn contributed to improvements in capacity (Burns 2003; Naughton 2005).

political virtue out of government modernisation, such as Lee Kwan Yew in Singapore and Mahathir Mohamad in Malaysia in the 1980s, who used their authority to create special units in their respective prime ministerial offices to drive the reform process. Some categories of reform are motivated by the desire to preserve social stability and to prevent public discontent (in response to poor governance) from posing a threat. ${ }^{8}$

Technological innovation is an important source of reform and facilitates new types of reform centred on e-governance initiatives that can produce significant changes through the applied use of information and communications technology (ICT) (computerisation, information storage and retrieval and communications). Access to information initiatives is also made possible through the active adoption of new technology.

\subsection{Record of governance initiatives in Asia} Asian governments have devised a range of governance initiatives to improve the accountability, efficiency and performance of state institutions. These can be divided into (a) administrative reforms which aim to strengthen core state functions and the transparency and accountability of government, and (b) decentralisation and service delivery reforms designed to promote voice and accountability in local government. The latter set of reforms have greater potential to make a direct contribution to poverty reduction by widening participation in decision making and ensuring that resources are directed to where they are most needed through improved allocative efficiency.

\section{Administrative reforms}

Administrative reforms include civil service reform, accountability reform and managerial reform (Schneider and Heredia 2003). Civil service reforms aim to improve incentives for public servants and make structural changes that reduce staff numbers, reorganise departments and limit state functions. Accountability reforms aim to prevent the abuse of power and improve responsiveness to citizens through improved legislative oversight, anticorruption initiatives and measures to strengthen transparency, such as e-governance. Managerial reforms aim to improve the efficiency of the civil service by encouraging competition, outsourcing, and the creation of arms-length executive agencies (Nunberg 1995). These reforms are often combined in different ways and may not be mutually exclusive, but such distinctions highlight the feasibility and potential entry points for different reform strategies. $^{9}$

Few governments in the region have developed ambitious civil service reform programmes entailing significant retrenchment on account of their political sensitivity. Only where the repercussions of making large numbers of civil servants redundant can be accommodated politically does one find evidence of such reforms.

While the significance of civil service reform for improving public sector management has been acknowledged by successive governments in India, there has been limited progress on structural change and administrative reorganisation due to the sensitivity and difficulty of this type of reform. Efforts to downsize the bureaucracy have usually encountered stiff resistance from trade unions or political parties seeking to derive political capital from opposition to such measures, as state governments in Andhra Pradesh and Madhya Pradesh found to their cost. But the government of India appointed a new Administrative Reforms Commission in August 2005, charged with identifying measures for overhauling India's administrative system, which signals fresh political commitment. 


\section{Box 2 E-governance initiatives in India}

Several governments have actively pursued e-governance initiatives as a means of improving the transparency and efficiency of government operations. E-governance initiatives also have the advantage of being less politically sensitive and can galvanise support from citizens who benefit from speedier transactions and reduced corruption. The Bhoomi programme in the south Indian state of Karnataka, which entails the computerisation of land records, is welcomed by farmers who can access information on landholdings in less time and with greater accuracy. E-governance is used by the state governments of Maharashtra and Andhra Pradesh to speed up the processing and payment of property taxes, which reduces the scope for arbitrary action by government officials and builds public support for 'small solutions'.

More commonplace and politically palatable are administrative reforms designed to improve incentives. These include pay and pension reform, improved recruitment and promotion procedures, and better training opportunities. Many governments in the region have pursued these types of measures with varying degrees of success. Malaysia overhauled the pay and promotion system for the civil service in the early 1990s to strengthen the merit principle and systematise performance-based enhancements. India substantially improved salary levels for civil servants following the recommendations of the Fifth Pay Commission in 1997 but did not follow through with broader governance reforms and reductions in the core civil service as proposed by the commission. China introduced an examination-based entry system for the civil service to enhance professional standards, and has upgraded formative training for new entrants. The government of Pakistan has embarked on a large-scale professional development programme for senior civil servants in federal and provincial governments to upgrade skills and capacity in the public service.

\section{Financial management reforms}

Financial management reforms have been pursued with vigour by a number of governments in the region. These have the advantage of having a lower political profile, they are unlikely to provoke significant resistance, and can produce significant benefits in terms of improved transparency and efficiency.

The Cambodian government has implemented a series of activities to strengthen public financial management from the mid-1990s in the form of improvements to the budget system, public accounting and the audit system supported by new laws and regulations. A key element of the current financial management reform programme centres on reform to treasury operations and budget formulation and execution to strengthen the credibility of the budget process and improve financial accountability. Key features of this process are consistent promotion of reforms over an extended time-frame, demonstrable government ownership of the reform process, and the cumulative introduction of incremental reforms.

\section{Anti-corruption measures}

There has been much less progress with measures to combat corruption, which can provoke resistance from entrenched interests in the bureaucracy and

\section{Box 3 Financial management reforms in Bangladesh}

The Bangladesh government pursued a series of reforms in budgeting and expenditure control over a ten-year period from the mid-1990s. The aim was to introduce modern budgeting and expenditure management and control techniques through improved accounting procedures, computerisation and capacity building. The reforms only had modest impact in the initial stages since they ran into opposition from entrenched interests in the bureaucracy, which resisted new ways of working. Critical to success was an incremental approach to reform with built-in flexibility that allowed for adjustments, a high level of domestic ownership, and consistent leadership at the top level. In the later stage of the initiative, greater progress was achieved under the leadership of the Minister of Finance who exerted significant influence over the direction and pace of the project. While the more ambitious objectives of the programme were not realised, the initiative built a constituency for reform within the civil service and created a foundation for further stages of more ambitious reform. 
the white-collar trade unions. Asian governments recognise the problems caused by corruption, but few have taken comprehensive action to tackle it. ${ }^{10}$ The two best-known examples of successful initiatives to tackle corruption are from the two city states of Hong Kong and Singapore, where a combination of a well-resourced anti-corruption agency, effective follow-up and prosecution, and improved pay and conditions significantly reduced the extent of the problem."

Most Asian countries have set up similar bodies with varying degrees of success. $A$ review of anticorruption institutions in Vietnam, for example, highlights how deep-seated reforms require a lengthy process of reform on many fronts, centred on the creation of new institutions and a supportive legislative framework (Wescott 2002). The formation of the Anti-Corruption Commission in Indonesia was delayed by four years following parliamentary approval of anti-corruption legislation. Similarly, the government of Bangladesh introduced legislation governing the formation of a new Anti-Corruption Commission, but the process of implementation was rushed in response to donor pressure, the organisation lacks rules of operation, its effectiveness has been undermined, and consequently it lacks wider credibility.

\section{Decentralisation}

Decentralisation experiences have been driven both by political considerations and by the desire to improve local accountability and service delivery. India, Indonesia, the Philippines and Pakistan have all followed a big-bang approach with an emphasis on devolution of powers, while Bangladesh, Nepal and Sri Lanka have followed a cautious, incremental approach with limited devolution of power and resources. Political motivations for decentralisation have included building grassroots support for political parties (West Bengal in India), reducing provincial opposition to national government (Pakistan), and counteracting pressures for secession (Indonesia). China offers another motive for reform where local governments in selected zones have been invested with an entrepreneurial function in the service of economic growth.

In general, decentralisation has provided opportunities for large numbers of people, including women, to participate in local government bodies. However, service delivery outcomes have varied considerably and there is an absence of conclusive evidence to demonstrate the benefits of decentralisation for health and education. An approach to local governance bringing in multiple stakeholders and with a clear focus on resource issues potentially yields greater dividends for poverty reduction and service delivery than a narrow political formulation of the decentralisation agenda. For example, while political decentralisation is not a current government priority in Bangladesh, rural people have benefited from a stronger focus on service delivery in which a variety of actors, including local officials, NGOs, community organisations, central government agencies and the private sector, have all played a part. This does not mean that efforts to promote political decentralisation are unwarranted but that improvements at the local level can occur in the absence of elected local governments.

\subsection{Implementation and impact}

Broad-based, comprehensive governance reform is not evident in most Asian countries. There has been limited progress on civil service reform and downsizing of bureaucracies, uneven commitment to anti-corruption with limited evidence of successful implementation, and some progress with financial management reform. Reforms tend to be piecemeal and incremental, with modest success in improving systems, building incentives and strengthening capacity, in the process creating a stronger basis for more enduring institutional change. This highlights the importance of politically feasible approaches that emanate from domestic political commitment and are led by champions of reform within the bureaucracy. It points to the value of multiple, cumulative and progressive initiatives rather than one-off institutional reforms.

There is recognition that political factors are a critical determinant of the success of governance and institutional reform projects in Asia. However, institution building can encounter political obstacles which in turn undermine effective implementation. For example, new institutions in Indonesia designed to tackle governance problems such as the National Law Commission and the office of the Ombudsman have been under-funded and lack political support, highlighting the limitations of reform initiatives that do not receive adequate political backing. 
3.6 Implications for growth and poverty reduction While Asia as a whole has witnessed commendable growth and poverty reduction in the past 25 years, experience brings out at least three compelling rationales why a governance focus is likely to be central in the next phase of development.

First is the continuing scale of poverty in Asia. Seven out of ten of the world's poor still reside in Asia. Obviously, the scale of the challenge means that considerable time will be required to eliminate the problem of poverty. More worrying is that across Asia, the success stories on growth are accompanied by the very visible phenomenon of social exclusion in terms of the large number of people left behind the spread of urban slums, low-quality rural service delivery, and a growing social divide in the quality of education. This growing problem of relative poverty, particularly in the most populous states such as Bangladesh, China, India, Indonesia, the Philippines and Pakistan, is generating social and political tensions which may derail the undoubted progress in growth and poverty reduction, and is a major governance challenge. Clearly, the urgency of ensuring pro-poor orientation of the growth process cannot be overstated.

Second, Asia is also witnessing more intensified vulnerabilities to natural disasters that put a premium on governance capacities. The 2004 tsunami and the 2005 earthquake in Kashmir provide a stark reminder of the disproportionate burden of these disasters on the poor, as well as the importance of institutionalising an effective response and building state capacity in terms of early warning and improved national and regional capacity for disaster mitigation and management.

A third emerging governance challenge in the region is that of personal security. Insecurity carries an economic price, especially in fragile states and regions, often translating into quantifiable income erosion (Rahman 1995). For example, the case of poor people in remote areas of Nepal highlights a perceived connection between poor services, insecurity and a deteriorating political environment. Even where opportunity frontiers are expanding, not all the available opportunities are accessed on account of the insecurities prevalent in the public domain. This is particularly true for women. The quality of the criminal justice system and access to affordable justice have become as important determinants of how well the poor are accommodated in the growth process as trade and investment policies.

\subsection{Examples of good practice in Asia}

Asian experience offers a rich diversity of successful governance initiatives. Examples extend not only to systemic initiatives but also to quality institutions, scaling up micro-initiatives, and programmatic interventions focused on specific needs. ${ }^{12}$

Experience in the region demonstrates that it is possible to achieve a high level of social development (and mitigate the worst manifestations of poverty) in the absence of a thriving economy if the government sets the right priorities. South Korea, Sri Lanka and Malaysia offer a variety of routes to high educational status, decreased child mortality and low fertility. Heavy social investment in these countries came early in their development process, despite low levels of per capita incomes at the time. Several common policy lessons emerge from this experience. First, the leading role of the state in the financing and provision of basic social services - regardless of whether the economy was centrally planned or market-oriented was critical. There was not exclusive reliance on the free play of market forces in service provision, nor on trickle-down of the benefits of economic growth. Second, high policy priority was given to health and education. Third, the equity and efficiency of spending was of paramount importance. Sustained public investments in basic services were possible because they were low in cost, and high in effectiveness. Fourth, as regards sequencing, investment in basic education preceded or accompanied the breakthrough in infant mortality reduction and expansion in public health provision. The synergies between interventions in health and education are critical to the success of each and increase the return to each investment. Finally, underlying all the above, lay women's agency, i.e. the freedom conferred on women to work outside the home, the freedom to earn an independent income and the freedom to have independent property rights.

Asia offers many examples of quality institutions that contribute to positive governance outcomes. The anti-corruption agencies of Singapore and Hong Kong are widely recognised for the impact they have had in tackling corruption in those city states. Less well known is the emergence of the Election Commission in India as a vital actor in disciplining the 


\section{Box 4 Local government and rural roads in Bangladesh}

A very different type of quality institution with significant implications for economic growth is the Local Government Engineering Department (LGED) in Bangladesh. Drawing on traditions rooted in the Comilla integrated rural development model of the 1960s and driven by charismatic leadership, the LGED emerged as a strategic service agency within the bureaucratic reality of a post-colonial state, spearheading the creation of rural infrastructure. Since coming to the fore in the early 1990s, LGED's rural roads have contributed to a growth dynamic in which many parts of rural Bangladesh have been largely freed from the curse of remoteness, the physical reality of an integrated national economy has been expedited, and the poor have become increasingly mobile and able to migrate to sources of employment. Key institutional aspects contributing to LGED's success have included: (1) organisational decentralisation, (2) a professional work culture and recognition of outstanding achievement, (3) a strong monitoring system, (4) informal decision making, de-emphasising bureaucratic file movement in favour of increased use of information technology, (5) leadership, (6) teamwork, and (7) a sense of mission. However, part of its success is also due to a pragmatic approach to accommodating political and financial pressures without impinging on work quality. Not surprisingly, the institution has proved to be adept in surviving in spite of a partisan political environment.

electoral process and thereby improving the functioning of Indian democracy. The importance of the Indian Election Commission lies not in any new legislation per se but rather in its emergence since the mid-1990s as an independent-minded body that is willing and able to assert the authority vested in it by law. Indeed, it is fair to say that governance problems often emanate from dormant capacities and lack of assertion even when legal provisions exist. It is precisely through greater assertiveness and by incrementally developing codes of conduct, clearer eligibility criteria and improved by-laws that the Indian Election Commission is transforming itself into a critical guardian of the democratic process.

A third category of good practice has been the successful scaling-up of proven local-level initiatives. Pioneered by committed social activists working in the context of rural development in the Indian state of Rajasthan, the campaign on right to information graduated to a national law in 2005. The transformation of this micro-level experience into national legislation resulted from a campaign which drew the support of the national political leadership and involved a protracted process of bargaining with civil society activists all the way through to the details of the legislation. The law is now a reality but, as with many policy windows, the real challenge now is how effectively the opportunity is utilised.

The fourth category of good practice is programmatic success on specific needs in otherwise poor governance environments. The sanitation campaign in Bangladesh provides a useful illustration of this process. Bangladesh appears poised to achieve the MDG target on sanitation. Key to this achievement is a number of interlinked factors. There is broad ownership of the agenda by the government. At the level of implementation, however, the key driver has been a mobilisational approach in which local governments, NGOs, community-based organisations (CBOs), the media and the private sector have all played a part. Critical to progress has also been the systematic identification of intermediate milestones - from open space defaecation to fixed-point defaecation, from hanging latrines into semi-sanitary ring-slab latrines, and finally the next and final stage, in which the goal is to universalise water-sealed ring-slab latrines. This low-threshold technology, i.e. production of concrete rings and slabs, has allowed for an impetus to localised production with a consequent boost to the local economy.

Another example of programmatic success has been the revolution in mobile telephony that is sweeping across poor countries and regions of South and South-east Asia. Poor people in rural areas now have much improved access to information and can communicate with the outside world in ways that were inconceivable a decade ago.

It may also be instructive to examine why some practices fail to graduate to the status of good practices. For example, substandard and insecure housing conditions are recognised as a crucial aspect of urban poverty. In most large cities in the developing world, the formal housing market serves 
only a minority of the population. It is estimated that 30-70 per cent live in 'irregular' settlements and that up to 85 per cent of the new housing stock is produced in an extra-legal manner. However, effective solutions to this problem have been slow in coming. Relocation schemes, social housing, slum upgrading and sites and services are beset by two related problems: they are far too small-scale to serve growing demand, and products are far too expensive to be affordable for low-income groups. The conventional sequence of planning-servicing-buildingoccupation has been identified by some as a key factor in both market and state failure (Mehrotra 2000). Each of these steps leads to a steep price increase and speculation, and in effect raw land is turned into a scarce and expensive commodity. Policy acceptance of the benefits that arise from reversing this conventional sequence may be critical to finding more effective and durable solutions.

However, South Asian experience suggests that not all implementation failures are due to design flaws. Lack of political will, improper sequencing, failure to anticipate and overcome implementation blockages, absence of participation, solutions that ignore ground realities, capacity deficits, ethical decay, and weak system development in the politicianadministrator interface are some of the critical factors explaining why positive initiatives do not graduate to the status of good practices.

\subsection{Success factors}

It may be useful to conclude this section by highlighting the success factors underlying positive experiences of governance reform and good practice in Asia. These include: (1) local ownership rather than external inducements through aid and conditionality; (2) political commitment based on recognition of potential benefits for growth and poverty reduction; (3) incremental reforms in state institutions focused on particular problem areas; (4) fostering of quality institutions with strategic potential for growth, poverty reduction and governance outcomes; and (5) creating demand and support for reform among clients of services and within civil society. The Asian experience also underscores the importance of an extended time horizon and incremental reforms and the cumulative value of small solutions over big solutions.

The fact that successful governance reform in Asia rests on local ownership, political commitment and incrementalism offers lessons for aid donors, who need to be in a better position to judge the prevailing political environment. Priorities are rarely homogenous across different social and political groups and a culture of pluralism creates an environment in which reform can be difficult to achieve. For example, donors rushed ahead with support for the Anti-Corruption Commission in Bangladesh before there was sufficient political support and credibility. More informed analysis of the political feasibility of competing reform options and closer attention to the timing and scope of reforms would strengthen the value of donor support for locally generated initiatives.

\section{Opportunities and entry points}

\subsection{Governance as an opportunity frontier}

Asia looms large on the global war on poverty. Enviable growth rates come with a burgeoning problem of inequality and relative poverty. Catastrophic vulnerabilities are a new threat. Although incomes are rising, their sustainability is less than certain. However, while home to seven out of ten of the world's poor, Asia also offers some of the most dynamic solutions to the challenge of graduation out of poverty.

As Asia considers its development trajectory over the next 25 years, governance has become a renewed opportunity frontier to address existing and emerging challenges to growth and poverty reduction. It is a frontier being forged in people's aspirations, ground-level practices, and a politically informed understanding of priorities.

From a governance perspective, initial conditions are not optimal, certainly not in the transitional societies of South Asia, Indonesia, the Philippines and the Mekong Delta countries. An uneasy interface of politicians and administrators, a 'winner takes all' approach to political competition and pressure from the electorate to deliver visible 'development results' all constitute a challenging environment in which a meaningful governance agenda has to be forged. And yet there are large dividends to be gained from an effective engagement on the governance frontier.

Five key lessons from the Asian experience need to inform the formulation of a new governance strategy in the service of growth and accelerated poverty reduction: 
1 Improving transparency and accountability in financial management is a crucial first-order reform agenda.

2 The state has been a critical actor in shaping successful development outcomes but the solutions have not been narrowly statist. The reformulation of the decentralisation agenda as one of local governance combining devolution, resource transfers and improved service delivery through the mobilisation of a range of local actors best encapsulates this lesson.

3 The intelligent pursuit of micro-level solutions and incremental approaches that build up a strategic momentum for further reform offer a crucial window of opportunity.

4 Targeted efforts on specific MDGs incorporating social mobilisational approaches and clear identification of intermediate milestones can fasttrack results.

5 Improved connectivity - physical and electronic can galvanise an empowered citizenry, which in turn becomes a powerful constituency for governance reforms.

\subsection{Unpacking solutions: a search for entry points}

While the broad contours of the governance agenda are clear, there is an operational challenge of unpacking solutions and identifying entry points for Asian governments which offer the greatest strategic promise and which satisfy the requirement of political feasibility. Seven such entry points can be highlighted.

\section{Innovative solutions for tackling corruption}

While the problem of corruption remains significant, an anti-corruption strategy narrowly focused on deterrence and sanctions has often proved ineffectual. What is often overlooked in donor-driven reform initiatives is the need to mobilise a critical coalition of operational actors and to establish clear incentives for performance.

For example, a new instrument being developed by the Ministry of Finance in Bangladesh with support from DFID will provide performance-based financing to sector ministries in response to governance reforms that demonstrably reduce leakage. These prospectively include a programme to reward improved school governance, the expansion of a stipend scheme for girls attending school, and community management of water supplies in Dhaka. The intention is that incremental progress in sector ministries provides a firmer basis for tackling corruption and reducing the wastage of public resources can be achieved through the creation of positive incentives for reform.

\section{Strategic ring-fencing to foster quality institutions} The political capacity to undertake and expedite systemic changes is often limited in transitional societies. An important second-best choice (typified as 'good enough governance') is to ring-fence certain strategic governance functions to facilitate the creation and insulation of critical pools of higher institutional quality and link these to larger strategic change processes (Grindle 2004). Securing political commitment to second-best choices may be more feasible than to more ambitious systemic reform agendas. The precise choice of institutions will vary across countries but is likely to include the Public Service Commission (for administrative recruitment), Election Commission (to serve as a political watchdog), Central Bank (financial management), the Supreme Audit institution (to ensure accountability), and the specialised economic policy units and infrastructure investment agencies. The argument about strategic ring-fencing can be extended to the issue of appointment to top positions in government. While partisan orientation has become a political reality in many countries, this need not by itself defeat governance objectives as long as eligibility standards are enforced through a meritocratic selection process.

\section{Promoting micro-level solutions}

Reformers have often overlooked the potential of micro-level solutions to governance problems. Strategically chosen micro-level solutions create visible results that can build reform momentum. Whether it is in the area of local government reform, criminal justice reform, changes to the land management system, or in the focus on quality in basic education, success is often determined by how effectively micro-level solutions have been identified and acted upon. Examples abound: the burden of private tutoring in primary education, the absence of user-friendly operational manuals, redundant paperwork, dormant capacities, community policing, decay in routine oversight and so on.

\section{Promoting a local governance approach to decentralisation and service delivery}

The traditional vocabulary of decentralisation sits uneasily with rapidly changing ground realities, which 
are far more sharply focused on service outcomes, old and new. Recent experience has produced a wide range of innovative ideas about how to improve service delivery through community engagement, contracting out, various forms of delegation, and privatisation; how to engage communities and municipalities in development planning and budget management; and how to build partnerships with NGOs, the private sector and communities across a wide range of service provision. Promoting such an approach to local governance while strengthening the preconditions for the transfer of adequate resource and administrative powers is likely to yield large dividends for Asia's poor.

\section{Rekindling a public service ethic}

The importance of an ethically committed political and administrative class in the emerging governance agenda cannot be overemphasised. Capacity building and training strategies typically have a narrow technical focus and are not conversant with real-life problems. An equally serious drawback has been a lack of engagement with public service and ethical concerns, a drawback also encountered in the NGO and corporate worlds. The challenge is both to deepen a social discourse and develop specific training possibilities that can pass the tests of social credibility and client interest.

\section{Meaningful indices and evidence on governance}

The quality and efficacy of the governance discourse often suffers from poor standards of knowledge of the process and indicators that can capture such knowledge. In the absence of such knowledge, a stereotypical understanding of governance problems often prevails, making consensus-building for viable intervention difficult. This is most evident in the case of popular perceptions of corruption that reflect everyday experience and in the great interest shown by the media to the corruption perceptions indices and surveys collected by international organisations. The development of domestic indicators to monitor progress and assist in agenda formulation, not just from the standpoint of international capital but also reflecting the aspirations of common people, offers the prospect of being a powerful driver for change.

\section{Strengthening choice and connectivity}

Governance goals are often facilitated when competition and choice become fundamental features of physical and social life. Remoteness renders the possibility of redress so much more difficult. The expansion of rural road networks can free rural populations from ties of local dependence and expand choice horizons. Mobile telephony has considerable potential for further information empowerment. Asia in general has had a sustained focus on improved connectivity. E-governance initiatives using ICT have considerable potential. However, much remains to be achieved and a focus on improved connectivity, both nationally and regionally, remains a continuing priority.

\subsection{Implications for partnerships}

Asian governments can demonstrate leadership in the governance reform agenda in several critical ways: emphasising the importance of state capacity as a key factor in successful development outcomes; demonstrating how strengthening the quality of key institutions is more feasible than systemic reforms; showing that incremental, small-scale reforms have greater potential than big solutions; and highlighting and disseminating successful innovations in governance.

Aid donors have invested heavily in governance reform efforts but with uneven impacts. What positive lessons emanate from this experience and what are the implications for future partnerships with Asian governments and regional organisations? Aid donors can support governance reform efforts initiated by Asian governments by: moving from conditionality to positive encouragement; developing flexible aid instruments and mutual policy commitments; providing resources for innovative approaches (for example, performance-related initiatives to reduce leakage in service provision); selective provision of technical assistance and advice; and facilitating exchange of positive reform experience in the region and elsewhere. More consistent pursuit of donor harmonisation and alignment with respect to supporting improvements in governance would be welcomed by countries that continue to receive significant inflows of development assistance.

Learning from Asian-led approaches to governance has implications for bilateral partnerships between Asian countries and for the agendas of regional organisations. There is scope for more intensified exchange among Asian countries of experience of governance reforms that have successfully strengthened state capacities and enabled 


\begin{tabular}{|c|c|c|c|c|c|}
\hline \multicolumn{6}{|c|}{ Annex 1 Indicators of state effectiveness } \\
\hline Country & Indicator & $\begin{array}{l}\text { Most recent } \\
\text { value }\end{array}$ & Rank & Change & 1996 \\
\hline Afghanistan & $\begin{array}{l}\text { CPI (2005) } \\
\text { WBI - Voice and Accountability (2004) } \\
\text { WBI - Political Stability (2004) } \\
\text { WBI - Government Effectiveness (2004) } \\
\text { WBI - Regulatory Quality (2004) } \\
\text { WBI - Rule of Law (2004) } \\
\text { WBI - Control of Corruption (2004) }\end{array}$ & $\begin{array}{l}2.5 \\
-1.35 \\
-2.03 \\
-1.24 \\
-2.05 \\
-1.81 \\
-1.33\end{array}$ & $\begin{array}{l}7 \\
11 \\
13 \\
13 \\
13 \\
13 \\
13\end{array}$ & $\begin{array}{l}\text { n/a } \\
+ \\
- \\
\text { n/a } \\
\text { n/a } \\
-- \\
\text { n/a }\end{array}$ & $\begin{array}{l}\mathrm{n} / \mathrm{a} \\
-1.53 \\
-1.82 \\
\mathrm{n} / \mathrm{a} \\
\mathrm{n} / \mathrm{a} \\
-1.19 \\
\mathrm{n} / \mathrm{a}\end{array}$ \\
\hline Bangladesh & $\begin{array}{l}\text { CPI (2005) } \\
\text { WBI - Voice and Accountability (2004) } \\
\text { WBI - Political Stability (2004) } \\
\text { WBI - Government Effectiveness (2004) } \\
\text { WBI - Regulatory Quality (2004) } \\
\text { WBI - Rule of Law (2004) } \\
\text { WBI - Control of Corruption (2004) }\end{array}$ & $\begin{array}{l}1.7 \\
-0.69 \\
-1.24 \\
-0.72 \\
-1.15 \\
-0.86 \\
-1.09\end{array}$ & $\begin{array}{l}13 \\
7 \\
9 \\
10 \\
12 \\
10 \\
12\end{array}$ & $\begin{array}{l}- \\
- \\
-- \\
- \\
-- \\
- \\
--\end{array}$ & $\begin{array}{l}2.29 \\
-0.33 \\
-0.53 \\
-0.67 \\
-0.54 \\
-0.68 \\
-0.47\end{array}$ \\
\hline Cambodia & $\begin{array}{l}\text { CPI (2005) } \\
\text { WBI - Voice and Accountability (2004) } \\
\text { WBI - Political Stability (2004) } \\
\text { WBI - Government Effectiveness (2004) } \\
\text { WBI - Regulatory Quality (2004) } \\
\text { WBI - Rule of Law (2004) } \\
\text { WBI - Control of Corruption (2004) }\end{array}$ & $\begin{array}{l}2.3 \\
-0.89 \\
-0.6 \\
-0.87 \\
-0.25 \\
-0.98 \\
-0.97\end{array}$ & $\begin{array}{l}10 \\
8 \\
5 \\
11 \\
5 \\
12 \\
11\end{array}$ & $\begin{array}{l}\text { n/a } \\
- \\
-- \\
- \\
\text { None } \\
- \\
\text { None }\end{array}$ & $\begin{array}{l}\mathrm{n} / \mathrm{a} \\
-0.68 \\
-1.15 \\
-0.58 \\
-0.29 \\
-0.91 \\
-0.94\end{array}$ \\
\hline China & $\begin{array}{l}\text { CPI (2005) } \\
\text { WBI - Voice and Accountability (2004) } \\
\text { WBI - Political Stability (2004) } \\
\text { WBI - Government Effectiveness (2004) } \\
\text { WBI - Regulatory Quality (2004) } \\
\text { WBI - Rule of Law (2004) } \\
\text { WBI - Control of Corruption (2004) }\end{array}$ & $\begin{array}{l}3.2 \\
-1.54 \\
-0.07 \\
0.11 \\
-0.45 \\
-0.47 \\
-0.51\end{array}$ & $\begin{array}{l}3 \\
12 \\
4 \\
3 \\
7 \\
5 \\
5\end{array}$ & $\begin{array}{l}++ \\
- \\
- \\
- \\
-- \\
\text { None } \\
--\end{array}$ & $\begin{array}{l}2.43 \\
-1.29 \\
0.27 \\
0.18 \\
-0.06 \\
-0.45 \\
-0.01\end{array}$ \\
\hline India & $\begin{array}{l}\text { CPI (2005) } \\
\text { WBI - Voice and Accountability (2004) } \\
\text { WBI - Political Stability (2004) } \\
\text { WBI - Government Effectiveness (2004) } \\
\text { WBI - Regulatory Quality (2004) } \\
\text { WBI - Rule of Law (2004) } \\
\text { WBI - Control of Corruption (2004) }\end{array}$ & $\begin{array}{l}2.9 \\
0.27 \\
-0.81 \\
-0.04 \\
-0.59 \\
-0.09 \\
-0.31\end{array}$ & $\begin{array}{l}5 \\
1 \\
6 \\
4 \\
8 \\
4 \\
4\end{array}$ & $\begin{array}{l}+ \\
\text { None } \\
\text { None } \\
+ \\
-- \\
- \\
\text { None }\end{array}$ & $\begin{array}{l}2.63 \\
0.28 \\
-0.77 \\
-0.14 \\
-0.09 \\
-0.01 \\
-0.31\end{array}$ \\
\hline Indonesia & $\begin{array}{l}\text { CPI (2005) } \\
\text { WBI - Voice and Accountability (2004) } \\
\text { WBI - Political Stability (2004) } \\
\text { WBI - Government Effectiveness (2004) } \\
\text { WBI - Regulatory Quality (2004) } \\
\text { WBI - Rule of Law (2004) } \\
\text { WBI - Control of Corruption (2004) }\end{array}$ & $\begin{array}{l}2.2 \\
-0.44 \\
-1.38 \\
-0.36 \\
-0.42 \\
-0.91 \\
-0.9\end{array}$ & $\begin{array}{l}11 \\
6 \\
10 \\
8 \\
6 \\
11 \\
10\end{array}$ & $\begin{array}{l}- \\
++ \\
-- \\
-- \\
-- \\
-- \\
--\end{array}$ & $\begin{array}{l}2.65 \\
-1.15 \\
-0.45 \\
0.18 \\
0.27 \\
-0.36 \\
-0.47\end{array}$ \\
\hline Malaysia & $\begin{array}{l}\text { CPI (2005) } \\
\text { WBI - Voice and Accountability (2004) } \\
\text { WBI - Political Stability (2004) }\end{array}$ & $\begin{array}{l}5.1 \\
-0.36 \\
0.38\end{array}$ & $\begin{array}{l}1 \\
5 \\
1\end{array}$ & $\begin{array}{l}\text { None } \\
+ \\
--\end{array}$ & $\begin{array}{l}5.32 \\
-0.05 \\
0.95\end{array}$ \\
\hline
\end{tabular}




\begin{tabular}{|c|c|c|c|c|c|}
\hline \multicolumn{6}{|c|}{ Annex 1 Indicators of state effectiveness (cont.) } \\
\hline Country & Indicator & $\begin{array}{l}\text { Most recent } \\
\text { value }\end{array}$ & Rank & Change & 1996 \\
\hline $\begin{array}{l}\text { Malaysia } \\
\text { (cont.) }\end{array}$ & $\begin{array}{l}\text { WBI - Government Effectiveness (2004) } \\
\text { WBI - Regulatory Quality (2004) } \\
\text { WBI - Rule of Law (2004) } \\
\text { WBI - Control of Corruption (2004) }\end{array}$ & $\begin{array}{l}0.99 \\
0.44 \\
0.52 \\
0.29\end{array}$ & $\begin{array}{l}1 \\
1 \\
1 \\
1\end{array}$ & $\begin{array}{l}- \\
-- \\
- \\
-\end{array}$ & $\begin{array}{l}1.07 \\
0.86 \\
0.85 \\
0.51\end{array}$ \\
\hline Nepal & $\begin{array}{l}\text { CPI (2005) } \\
\text { WBI - Voice and Accountability (2004) } \\
\text { WBI - Political Stability (2004) } \\
\text { WBI - Government Effectiveness (2004) } \\
\text { WBI - Regulatory Quality (2004) } \\
\text { WBI - Rule of Law (2004) } \\
\text { WBI - Control of Corruption (2004) }\end{array}$ & $\begin{array}{l}2.5 \\
-1 \\
-1.74 \\
-0.9 \\
-0.6 \\
-0.82 \\
-0.61\end{array}$ & $\begin{array}{l}7 \\
9 \\
12 \\
12 \\
10 \\
9 \\
7\end{array}$ & $\begin{array}{l}\mathrm{n} / \mathrm{a} \\
-- \\
-- \\
-- \\
- \\
-- \\
-\end{array}$ & $\begin{array}{l}\mathrm{n} / \mathrm{a} \\
0.14 \\
-0.35 \\
-0.38 \\
-0.22 \\
-0.36 \\
-0.28\end{array}$ \\
\hline Pakistan & $\begin{array}{l}\text { CPI (2005) } \\
\text { WBI - Voice and Accountability (2004) } \\
\text { WBI - Political Stability (2004) } \\
\text { WBI - Government Effectiveness (2004) } \\
\text { WBI - Regulatory Quality (2004) } \\
\text { WBI - Rule of Law (2004) } \\
\text { WBI - Control of Corruption (2004) }\end{array}$ & $\begin{array}{l}2.1 \\
-1.31 \\
-1.59 \\
-0.57 \\
-1.03 \\
-0.78 \\
-0.87\end{array}$ & $\begin{array}{l}12 \\
10 \\
11 \\
9 \\
11 \\
8 \\
9\end{array}$ & $\begin{array}{l}- \\
- \\
- \\
- \\
-- \\
- \\
+\end{array}$ & $\begin{array}{l}2.53(1997) \\
-0.98 \\
-1.21 \\
-0.4 \\
-0.57 \\
-0.44 \\
-0.98\end{array}$ \\
\hline Philippines & $\begin{array}{l}\text { CPI (2005) } \\
\text { WBI - Voice and Accountability (2004) } \\
\text { WBI - Political Stability (2004) } \\
\text { WBI - Government Effectiveness (2004) } \\
\text { WBI - Regulatory Quality (2004) } \\
\text { WBI - Rule of Law (2004) } \\
\text { WBI - Control of Corruption (2004) }\end{array}$ & $\begin{array}{l}2.5 \\
0.02 \\
-1.01 \\
-0.23 \\
-0.06 \\
-0.62 \\
-0.55\end{array}$ & $\begin{array}{l}7 \\
3 \\
7 \\
5 \\
4 \\
7 \\
6\end{array}$ & $\begin{array}{l}- \\
- \\
-- \\
-- \\
-- \\
-- \\
-\end{array}$ & $\begin{array}{l}3.05(1997) \\
0.17 \\
-0.12 \\
0.19 \\
0.45 \\
-0.11 \\
-0.4\end{array}$ \\
\hline Sri Lanka & $\begin{array}{l}\text { CPI (2005) } \\
\text { WBI - Voice and Accountability (2004) } \\
\text { WBI - Political Stability (2004) } \\
\text { WBI - Government Effectiveness (2004) } \\
\text { WBI - Regulatory Quality (2004) } \\
\text { WBI - Rule of Law (2004) } \\
\text { WBI - Control of Corruption (2004) }\end{array}$ & $\begin{array}{l}3.2 \\
-0.16 \\
-1.06 \\
-0.27 \\
0.21 \\
-0.03 \\
-0.16\end{array}$ & $\begin{array}{l}3 \\
4 \\
8 \\
6 \\
2 \\
2 \\
2\end{array}$ & $\begin{array}{l}- \\
\text { None } \\
-- \\
\text { None } \\
- \\
- \\
+\end{array}$ & $\begin{array}{l}\mathrm{n} / \mathrm{a} \\
-0.21 \\
-1.73 \\
-0.3 \\
0.34 \\
0.29 \\
-0.23\end{array}$ \\
\hline Vietnam & $\begin{array}{l}\text { CPI (2005) } \\
\text { WBI - Voice and Accountability (2004) } \\
\text { WBI - Political Stability (2004) } \\
\text { WBI - Government Effectiveness (2004) } \\
\text { WBI - Regulatory Quality (2004) } \\
\text { WBI - Rule of Law (2004) } \\
\text { WBI - Control of Corruption (2004) }\end{array}$ & $\begin{array}{l}2.6 \\
-1.54 \\
0.16 \\
-0.31 \\
-0.57 \\
-0.59 \\
-0.74\end{array}$ & $\begin{array}{l}6 \\
12 \\
2 \\
7 \\
9 \\
6 \\
8\end{array}$ & $\begin{array}{l}- \\
- \\
- \\
- \\
\text { None } \\
- \\
-\end{array}$ & $\begin{array}{l}2.79(1997) \\
-1.31 \\
0.4 \\
-0.1 \\
-0.56 \\
-0.5 \\
-0.64\end{array}$ \\
\hline
\end{tabular}

CPI: The Corruption Perceptions Index gives higher values for lower levels of corruption. It is based on the perceptions of corruption expressed by expert analysts and business people in a variety of surveys.

WBI: The World Bank Institute variables are normalised to 0 , and range from -2.5 to 2.5 , with higher values indicating better performance. They are based on the aggregation of a range of governance surveys and indicators. Because the values are normalised from year to year, changes are not absolute changes but, instead, measures of change relative to other countries. 


\begin{tabular}{|c|c|c|c|c|c|}
\hline \multicolumn{6}{|c|}{ Annex 2 Indicators of civil and political rights } \\
\hline Country & Indicator & $\begin{array}{l}\text { Most recent } \\
\text { value }\end{array}$ & Rank & Change & 1996 \\
\hline Afghanistan & $\begin{array}{l}\text { Freedom House - 'Political Rights' (2005) } \\
\text { Freedom House - 'Civil Liberties' (2005) } \\
\text { Polity IV - Polity II (2003) } \\
\text { CIRI - Physical Integrity Rights (2005) } \\
\text { CIRI - Empowerment Rights (2005) }\end{array}$ & $\begin{array}{l}5 \\
6 \\
n / a \\
n / a \\
2\end{array}$ & $\begin{array}{l}8 \\
11 \\
13 \\
13 \\
8\end{array}$ & $\begin{array}{l}++ \\
+ \\
\text { n/a } \\
\text { n/a } \\
-\end{array}$ & $\begin{array}{l}7 \\
7 \\
-7 \\
0(1997) \\
3\end{array}$ \\
\hline Bangladesh & $\begin{array}{l}\text { Freedom House - 'Political Rights' (2005) } \\
\text { Freedom House - 'Civil Liberties' (2005) } \\
\text { Polity IV - Polity II (2003) } \\
\text { CIRI - Physical Integrity Rights (2005) } \\
\text { CIRI - Empowerment Rights (2005) }\end{array}$ & $\begin{array}{l}4 \\
4 \\
6 \\
1 \\
4\end{array}$ & $\begin{array}{l}6 \\
5 \\
4 \\
6 \\
6\end{array}$ & $\begin{array}{l}- \\
\text { None } \\
\text { None } \\
- \\
--\end{array}$ & $\begin{array}{l}3 \\
4 \\
6 \\
3 \\
7\end{array}$ \\
\hline Cambodia & $\begin{array}{l}\text { Freedom House - 'Political Rights' (2005) } \\
\text { Freedom House - 'Civil Liberties' (2005) } \\
\text { Polity IV - Polity II (2003) } \\
\text { CIRI - Physical Integrity Rights (2005) } \\
\text { CIRI - Empowerment Rights (2005) }\end{array}$ & $\begin{array}{l}6 \\
5 \\
2 \\
4 \\
5\end{array}$ & $\begin{array}{l}10 \\
8 \\
7 \\
2 \\
4\end{array}$ & $\begin{array}{l}\text { None } \\
+ \\
- \\
+ \\
-\end{array}$ & $\begin{array}{l}6 \\
6 \\
1 \\
2 \\
7\end{array}$ \\
\hline China & $\begin{array}{l}\text { Freedom House - 'Political Rights' (2005) } \\
\text { Freedom House - 'Civil Liberties' (2005) } \\
\text { Polity IV - Polity II (2003) } \\
\text { CIRI - Physical Integrity Rights (2005) } \\
\text { CIRI - Empowerment Rights (2005) }\end{array}$ & $\begin{array}{l}7 \\
6 \\
-7 \\
1 \\
0\end{array}$ & $\begin{array}{l}12 \\
11 \\
10 \\
6 \\
12\end{array}$ & $\begin{array}{l}\text { None } \\
+ \\
\text { None } \\
+ \\
\text { None }\end{array}$ & $\begin{array}{l}7 \\
7 \\
-7 \\
0 \\
0\end{array}$ \\
\hline India & $\begin{array}{l}\text { Freedom House - 'Political Rights' (2005) } \\
\text { Freedom House - 'Civil Liberties' (2005) } \\
\text { Polity IV - Polity II (2003) } \\
\text { CIRI - Physical Integrity Rights (2005) } \\
\text { CIRI - Empowerment Rights (2005) }\end{array}$ & $\begin{array}{l}2 \\
3 \\
9 \\
0 \\
6\end{array}$ & $\begin{array}{l}1 \\
1 \\
1 \\
11 \\
3\end{array}$ & $\begin{array}{l}++ \\
+ \\
\text { None } \\
\text { None } \\
--\end{array}$ & $\begin{array}{l}4 \\
4 \\
9 \\
0 \\
9\end{array}$ \\
\hline Indonesia & $\begin{array}{l}\text { Freedom House - 'Political Rights' (2005) } \\
\text { Freedom House - 'Civil Liberties' (2005) } \\
\text { Polity IV - Polity II (2003) } \\
\text { CIRI - Physical Integrity Rights (2005) } \\
\text { CIRI - Empowerment Rights (2005) }\end{array}$ & $\begin{array}{l}3 \\
4 \\
-7 \\
1 \\
2\end{array}$ & $\begin{array}{l}4 \\
5 \\
10 \\
6 \\
8\end{array}$ & $\begin{array}{l}++ \\
++ \\
\text { None } \\
- \\
+\end{array}$ & $\begin{array}{l}7 \\
6 \\
-7 \\
3 \\
1\end{array}$ \\
\hline Malaysia & $\begin{array}{l}\text { Freedom House - 'Political Rights' (2005) } \\
\text { Freedom House - 'Civil Liberties' (2005) } \\
\text { Polity IV - Polity II (2003) } \\
\text { CIRI - Physical Integrity Rights (2005) } \\
\text { CIRI - Empowerment Rights (2005) }\end{array}$ & $\begin{array}{l}4 \\
4 \\
3 \\
4 \\
1\end{array}$ & $\begin{array}{l}6 \\
5 \\
6 \\
2 \\
11\end{array}$ & $\begin{array}{l}\text { None } \\
+ \\
\text { None } \\
- \\
--\end{array}$ & $\begin{array}{l}4 \\
5 \\
3 \\
5 \\
5\end{array}$ \\
\hline Nepal & $\begin{array}{l}\text { Freedom House - 'Political Rights' (2005) } \\
\text { Freedom House - 'Civil Liberties' (2005) } \\
\text { Polity IV - Polity II (2003) } \\
\text { CIRI - Physical Integrity Rights (2005) } \\
\text { CIRI - Empowerment Rights (2005) }\end{array}$ & $\begin{array}{l}5 \\
5 \\
-6 \\
0 \\
4\end{array}$ & $\begin{array}{l}8 \\
8 \\
9 \\
12 \\
6\end{array}$ & $\begin{array}{l}-- \\
- \\
-- \\
-- \\
-\end{array}$ & $\begin{array}{l}3 \\
4 \\
5 \\
5 \\
5\end{array}$ \\
\hline Pakistan & $\begin{array}{l}\text { Freedom House - 'Political Rights' (2005) } \\
\text { Freedom House - 'Civil Liberties' (2005) } \\
\text { Polity IV - Polity II (2003) } \\
\text { CIRI - Physical Integrity Rights (2005) }\end{array}$ & $\begin{array}{l}6 \\
5 \\
-5 \\
1\end{array}$ & $\begin{array}{l}10 \\
8 \\
8 \\
6\end{array}$ & $\begin{array}{l}-- \\
\text { None } \\
-- \\
\text { None }\end{array}$ & $\begin{array}{l}3 \\
5 \\
8 \\
1\end{array}$ \\
\hline
\end{tabular}


Annex 2 Indicators of civil and political rights (cont.)

\begin{tabular}{llllll}
\hline Country & Indicator & $\begin{array}{l}\text { Most recent } \\
\text { value }\end{array}$ & Rank & Change & 1996 \\
\hline \multirow{2}{*}{ Pakistan (cont) } & CIRI - Empowerment Rights (2005) & 2 & 8 & + & 1 \\
Philippines & Freedom House - 'Political Rights' (2005) & 2 & 1 & None & 2 \\
& Freedom House - 'Civil Liberties' (2005) & 3 & 1 & + & 4 \\
& Polity IV - Polity II (2003) & 8 & 3 & None & 8 \\
& CIRI - Physical Integrity Rights (2005) & 1 & 6 & None & 1 \\
& CIRI - Empowerment Rights (2005) & 7 & 1 & None & 7 \\
\multirow{5}{*}{ Sri Lanka } & Freedom House - 'Political Rights' (2005) & 3 & 4 & + & 4 \\
& Freedom House - 'Civil Liberties' (2005) & 3 & 1 & + & 5 \\
& Polity IV - Polity II (2003) & 6 & 4 & + & 5 \\
& CIRI - Physical Integrity Rights (2005) & 5 & 1 & ++ & 0 \\
& CIRI - Empowerment Rights (2005) & 5 & 4 & -- & 9 \\
Vietnam & Freedom House - 'Political Rights' (2005) & 7 & 12 & None & 7 \\
& Freedom House - 'Civil Liberties' (2005) & 6 & 11 & + & 7 \\
& Polity IV - Polity II (2003) & -7 & 10 & None & -7 \\
& CIRI - Physical Integrity Rights (2005) & 3 & 5 & - & 5 \\
& CIRI - Empowerment Rights (2005) & 0 & 12 & None & 0
\end{tabular}

Freedom House rankings use a scale from 1 to 7 , giving high values to indicate low levels of political freedom and civil liberties. The values are based on expert assessments.

The Physical Integrity Rights Index takes values from 0 (no rights) to 8 (total rights). The variable is an aggregate of rankings for torture, extrajudicial killings, political imprisonment and disappearance. It is based on the frequency with which physical integrity violations are reported in the US State Department Country Reports on Human Rights and Amnesty International's Annual Report.

The Empowerment Rights Index takes values from 0 (no rights) to 8 (total rights). It is an aggregate measure of indicators related to freedom of movement, freedom of speech, workers' rights, political participation and freedom of religion. It is based on the extent of rights are reported in the US State Department Country Reports on Human Rights.

The Polity IV dataset measures aspects of regime authority and regime stability, based on relatively quantitative measures of state characteristics. The Polity II variable is a composite variable indicating the degree of democracy in the polity, and takes values from -10 (low) to 10 (high). It incorporates variables measuring electoral openness, electoral competitiveness, constraints on the executive and levels of political participation

n/a: Not available. 
government agencies to broaden citizen participation and foster accountability. Successful models of public administration reform and innovative tools for capacity strengthening could be more actively shared through country-level training institutions. Study tours and bilateral exchanges of officials between countries in the region would foster greater awareness of positive experiences within the region and lessen the emphasis on borrowing from OECD (Organisation for Economic Co-operation and Development) experience. Positive experience of governance reform in the region could be documented more systematically and fed into the curricula of international public administration and training institutions.

Finally, regional organisations such as the South Asian Association for Regional Cooperation (SAARC)

\section{Notes}

1 For example, see World Bank (1997) and Khan (2002) for contrasting approaches.

2 Elaborated in a speech on 3 February 2006 by the UK International Development Secretary Hilary Benn, available at http://politics.guardian.co.uk/ development/story/ 0,,1701411,00.html

3 This resonates closely with the 'good enough governance' agenda promoted by Grindle (2004).

4 Also see East Asia Barometer: A Comparative Survey of Democratisation and Value Changes, http://eacsurvey.law.ntu.edu.tw; for the Asian Survey Barometer, see www.ipsas.sinica.edu.tw and the State of Democracy in South Asia report at www.lokniti.org

5 See, for example, Paul (2002).

6 Power and Participation Research Centre (PPRC) 2006, Bangladesh Annual Governance and Social Trends Report (forthcoming).

7 These are the Public Service Division and the Public Service in the 21st Century (PS21) in Singapore (http://app.psd.gov.sg) and the Malaysian Administrative Modernisation and Management Planning Unit (MAMPU) (http://mcsl.mampu.gov.my/english) in Malaysia. and the Association of Southeast Asian Nations (ASEAN) are taking a more active interest in promoting successful models of governance and public sector reform in member states that have had a positive bearing on growth and poverty reduction outcomes. Based on the experience of the Independent South Asian Commission on Poverty Alleviation (ISACPA), SAARC is well positioned to take a lead in collating knowledge and developing indicators of governance that better reflect regional priorities and experience. With the adoption of the 2020 Vision in 1997, ASEAN has declared its intention to place capacity building and harmonisation of policies at the centre of its development cooperation efforts. Such efforts provide a firm foundation for future Asian leadership in developing strategies for strengthening state effectiveness and governance in the region.

8 This might prove to be an important impetus for local governance reform in China as a means of quelling rural discontent over poor services and lack of accountability.

9 It could be argued that managerial reforms should encompass accountability reforms on the grounds that good management requires clarity in reporting and clear channels of accountability.

10 See, for example, ADB (2000). The ADB states that corruption can cost up to one-sixth of a country's GDP in the Asia-Pacific region. See www.adb.org/Governance/gov_anti.asp

11 See Kim (2002) for an account. Website resources are the Independent Commission Against Corruption (ICAC) Hong Kong, www.icac.org.hk/eng, and Singapore's Corrupt Practices Investigation Bureau (CPIB) at www.cpib.gov.sg

12 Independent South Asian Commission on Poverty Alleviation (ISACPA), 2004, Our Future, Our Responsibility, Kathmandu. 


\section{References}

ADB (2000) Taking Action against Corruption in the Asian and Pacific Economies, Manila: Asian Development Bank

Burns, J.P. (2003) 'Governance and Public Sector Reform in the People's Republic of China', in A.B.L. Cheung and I. Scott (eds), Governance and Public Sector Reform in the Asia Pacific: Paradigm Shift or Business as Usual?, London and New York: Routledge Curzon: 66-89

Cheung, A.B.L. and Scott, I. (2003a) Governance and Public Sector Reforms in the Asia Pacific: Paradigms, Paradoxes and Dilemmas, London and New York: Routledge Curzon: 1-24

Cheung, A.B.L. and Scott, I. (2003b) Governance and Public Sector Reform in Asia: Paradigm Shift or Business as Usual?, London and New York: Routledge Curzon

Dalton, R.J. and Shin, D.C. (2003) 'Democratic Aspirations and Democratic Ideals: Citizen Orientations Towards Democracy in East Asia', unpublished paper

Grindle, M.S. (2004) 'Good Enough Governance: Poverty Reduction and Reform in Developing Countries', Governance 17.4: 525-48

Khan, M. (2002) 'State Failure in Developing Countries and Institutional Reform Strategies', paper presented at the ABCDE Conference, Oslo

Kim, T. (2002) 'Comparative Study of AntiCorruption Systems, Efforts and Strategies in Asian Countries: Focusing on Hong Kong, Singapore, Malaysia, and Korea', in J. Kidd and F. -J. Richter (eds), Fighting Corruption in Asia: Causes, Effects and Remedies, Basingstoke: Palgrave Macmillan

Manor, J. (2006) Successful Governance Reforms in Two Indian States: Karnataka and Andhra Pradesh, IDS Discussion Paper 385, Brighton: IDS

Masud, M.O. (2002) Co-producing Citizen Security: The Citizen-Police Liaison Committee in Karachi, IDS Working Paper 172, Brighton: IDS

Mehrotra, S. (2000) Integrating Economic and Social Policy: Good Practices from High-Achieving
Countries, New York: UNICEF,

www.unicef-icdc.org

Naughton, B. (2005) 'China's Political System and China's Future Growth', in Woodrow Wilson International Centre for Scholars, China's Economy: Retrospect and Prospect, Asia Program Special Report 129, July

Nunberg, B. (1995) Managing the Civil Service: Reform Lessons from Advanced Industrialized Countries, World Bank Discussion Paper 204, Washington DC: World Bank

Paul, S. (2002) Holding the State to Account: Citizen Monitoring in Action, Bangalore: Books for Change

Rahman, H.Z. (2005) Engaging on "Good Governance": A Search for Entry Points, PPRC Policy Brief, Dhaka: Power and Participation Research Centre

Rahman, H.Z. (1995) 'Crisis and Insecurity: The Other Face of Poverty' in Rahman and Hossain (eds), Rethinking Rural Poverty, New Delhi: SAGE Publications

Rahman, H.Z. and Aminul Islam, S. (2002) Local Governance and Community Capacities: Search for New Frontiers, Dhaka: University Press Ltd

Schneider, B.R. and Heredia, B. (2003) Reinventing Leviathan: The Politics of Administrative Reform in Developing Countries, Coral Gables: North-South Center Press at the University of Miami

Weiss, L. (ed.) (2003) States in the Global Economy: Bringing Domestic Institutions Back In, Cambridge: Cambridge University Press

Wescott, C. (2002) 'Combating Corruption in Southeast Asia', in J. Kidd and F.-J. Richter (eds), Fighting Corruption in Asia: Causes, Effects and Remedies, Basingstoke: Palgrave Macmillan

World Bank (1997) World Development Report 1997: The State in a Changing World, Oxford: Oxford University Press

World Bank/ADB (Asian Development Bank) (2002) Poverty in Bangladesh: Building on Progress, Washington DC: World Bank, Poverty Reduction and Economic Management Unit, South Asia Region 